\title{
Appropriating the presence of history: raising the victory banner over the
}

\section{Reichstag}

The extreme high-angle photograph of a Red Army soldier, supported by a comrade, hoisting the Soviet flag from the roof of the Reichstag over the smouldering ruins of Berlin is a widely recognized iconic image of the end of World War II in Europe. Its filmic counterpart, black-and-white footage of the assault on the Reichstag, starts with many shots of an artillery barrage, taken from behind the guns, edited together with images of explosions. This is followed by an infantry assault on the building by a group of six soldiers holding a (presumably) red banner who run past a static camera into the foreground towards the recognizable facade and steps of the Reichstag. A cut takes us closer to the building, showing the group of flag-bearers running up the steps, past the columns and through a hole in the front. The final shots show the flag being raised on the roof, over an equestrian statue, as the pace of the montage quickens to a five-second shot-length, and the flag-raisers are shown in low-angle closeup, firing their weapons in a salute. Finally, a shot taken from a distance offers a panoramic view of the Reichstag building with the barely visible flag flying over it.

These photographic and filmic images representing the 30 April 1945's 'Raising of the Victory Banner Over the Reichstag' by Soviet soldiers are familiar representations of the end of World War II. Providing evidence of the Soviets' role in the defeat of the Nazis they continue to possess enormous resonance, especially within Russia and the former Soviet Union. While the production and circulation of the photographs of the Victory Banner have been widely discussed, ${ }^{1}$ the film images have received less attention until recently, ${ }^{2}$ although they have lent themselves to widespread 
reproduction across many contexts. From epic reenactments in colour and widescreen cinema; through numerous compilation documentaries, videogames, and television miniseries, they illustrate the capacity of iconic images to embody memory. According to Hariman and Lucaites, such images are 'fragmentary representations of events that reinforce dominant, totalizing narratives'. Yet these critics also argue that such images are semantically mutable sites of a democratic ideological contest specific to American public culture. ${ }^{3}$ To extend that account of iconic images beyond the liberal, western context, what follows is an attempt to gauge whether appropriations of the Victory Banner imagery across a range of mostly Russian and Soviet media from 1945 provide a necessary reassessment of these images, and to show how they draw repeatedly on the specifically cinematic connotations of the iconic film footage.

The still photograph taken by Evgenii Khaldei is probably the best known of the flag-raising event, although it is neither the only nor the first published photograph of this event. The photograph became widely known and reproduced in the print media from May 1945, partly due to its effective composition, ${ }^{4}$ a feature it supposedly shares with other iconic photographs. ${ }^{5}$ Drawing inspiration from Joe Rosenthal's February 1945 photograph, 'Flag Raising on Iwo Jima', ${ }^{6}$ it effectively mobilizes the symbolic potential of the scene and the moment.

The symbolism of the raising of the flag, black and white but implicitly red, with a hammer and sickle, the official flag of the Soviet Union, has dual associations of asserting the triumph of the Soviet state, and that of the wider socialist movement for whom the red flag had served as a symbol since the 1870 s. As towns were conquered or recaptured from the Nazis, from 1941 onwards the Soviets filmed or photographed 
the raising of the flag on a prominent building, but none of these images has been so widely reproduced as that of the Victory Banner over Berlin's Reichstag.

In addition to the fact that Berlin was the centre of Nazi power and thus its capture spelled their defeat, the Reichstag, previously the seat of the German parliament, was itself associated with Hitler's 1933 seizure of power, when an arson attempt on the building provided a pretext for a crackdown on Communist opponents. However, Khaldei includes no recognizable features such as the cupola or the columns and steps of the façade; only the text under the caption, 'The Victory Banner Over Berlin' indicates the flag is being raised over the Reichstag. What we see of the building are two statues in the background, which contrast with the living figures raising the flag yet seem human in size, implying that they too are viewing subjects who survey Berlin, a devastated city emitting plumes of smoke (an effect later enhanced by Khaldei). In this respect the image recalls Walter Hahn's February 1945 image of Dresden, taken from the town hall, in which a female statue appears to look over the cityscape. Ruins are said to echo other ruins, ${ }^{7}$ and these images therefore recall not only other German devastation but, also the destruction of Russian cities such as Stalingrad. At the same time they suggest a wider sense of catastrophe, inferring the historical perspective of the end of an empire, an era and a regime, just as falling statues later symbolized the fall of Communism or Saddam Hussein. Seen in this light, the red flag being raised above the ruins inaugurates a new epoch displacing Hitler's twelve-year Third Reich, and invites a distanced reflection on the historical moment, actually tempering the exaltation and triumphalism of the moment.

The most widely recognized film sequence of the flag-raising event appeared in Yulii Raizman's documentary Berlin (released in the USSR on 26 June, as The Fall of Berlin in the USA in October, and winning a prize at the inaugural 1946 Cannes film 
festival). In contrast to the still photographs' implicit historical perspective, the film footage suggests immediacy through its closeups of the flag-raisers, and the moment of battle in shots of the infantry assault, that, in being edited to match action, evoke a subjective camera. In Raizman's film this sense of immediacy is enhanced by the voiceover, which repeats the imperative 'Raise the Victory Banner over the Reichstag!' as the assault is launched. The imperative implies an order, and the sequence seems to show it being carried out before our eyes, in the present tense. This invocation of the immediate experience of combat, at the culminating point of the grand historical narrative, is crucial to later appropriations of the film footage of the Victory Banner across various media. While its authority, like that of the photographs, depended on a sense that they constitute an indexical record of this important historical event, the moving images simultaneously give a sense of presence, of being there.

In fact, while the symbolic act of flag-raising was intended from the outset to create a signifier of Soviet victory and the war's final moment, victory was not assured when the flag was first raised on 30 April, as German resistance continued in Berlin (including in the Reichstag itself) until 2 May, and the actual final surrender only came on 8 May, repeated for the Soviets on 9 May. ${ }^{8}$

Indeed, overcoming a long-standing taboo in the Soviet era on critical debate about the war, since the 1990s it has emerged that these images of the flag-raising were all staged after the event, since in fact it was a moment that could not be filmed or photographed due to it taking place at night with a consequent lack of lighting. ${ }^{9}$ The photographs were actually reenacted in the first days after the building's capture for a series of newspaper and magazine-publications. ${ }^{10}$ Yet, while the production and subsequent circulation of Khaldei's image have been widely discussed, ${ }^{11}$ there has 
been very little consideration of the newsreel footage, despite the fact that it has been even more widely appropriated, over a wide range of media, as an authoritative record of the event, and as an archival document illustrating the dominant Soviet interpretation of history.

The Russian documentary film archive dates the Victory Banner footage to 30 April, when the first flag was actually raised, but this is contradicted in memoir accounts, which record that the newsreel footage was filmed the next morning. ${ }^{12}$ These claims too are belied by previously unpublished correspondence between the camera crews in Berlin and the studio in Moscow, indicating that the images were recorded over ten days later, after the rushes of the initial restaging were found to be unusable. ${ }^{13}$ Indeed, prior to Raizman's film, the flag-raising sequence first appeared in a Soviet special-release newsreel, 'The Victory Banner Has Been Raised Above Berlin', dated 16 May 1945, but this film did not include recognizable images of the Reichstag facade, nor enough usable closeups of the flag-raisers. ${ }^{14}$ There is a particular irony here, in that this additional material recorded for Raizman's film, including that of the flag-bearing soldiers running towards the Reichstag facade, is the very footage that commonly strikes spectators with its immediacy, evoking the sense of being present at this event.

Moreover, despite Raizman's film being edited by Dziga Vertov's partner, Elizaveta Svilova, the potential discontinuity between shots - characteristic of avantgarde editing - is subordinated to the establishing shot and strong spatial and temporal continuity, creating a firm sense of place. Thus the Reichstag, and the act of flagraising, mark a fixed point in time: the end of the battle, of the Nazi regime and of the war. The authoritative voiceover underlines the epochal nature of the supposedly recorded event as historic, as the moment of victory, but to do so, it necessarily elides 
the time gap between the raising of the banner and the surrender of Berlin two days later, just as it is silent over the problematic use of the Reichstag, the pre-1933 seat of German democracy, as a symbol of Nazi Germany. The process of editing and reshooting has simplified the fragmentary chaos of violent combat into a smooth historical narrative of victory, framed by a moment of ultimate narrative closure, the raising of the Victory Banner signifying the end of World War II in Europe. Photographs, Barthes argues, ${ }^{15}$ freeze a moment: here it is that of victory, extended infinitely as a metonym for the conflict. The sequential nature of film as described by Deleuze, however, tends to present all instants as equal. ${ }^{16}$ Here this has to be overcome through the editing, creating a point of crescendo, and by explicitly verbalizing the significance of the flag-raising through the repeated imperatives of the assault, culminating in the use of a past tense as war is transformed into peace: 'The Victory Banner has been raised'. We are left with a quotable iconic film sequence of combat leading to triumph, a fragment that stands for the whole battle and can ultimately be used to stand for the whole war.

Before examining the ways in which other films have appropriated this sequence, we might first consider the ways of understanding World War II that are closed off by selecting this image of raising the Victory Banner. One significant effect of the film sequence is that, unlike Khaldei's photograph, it characterizes the war in terms of combat rather than the involvement of wider society. Its emphasis on the exclusively male sphere of the infantry also serves to push women out of view. In the Soviet context, where the mobilization of over half a million women as combatants in the Red Army, largely in more technically demanding roles, played a crucial part in victory, this is a significant bias, indicative of a wider postwar Soviet trend to 
suppress the female experience of wartime combat. ${ }^{17}$ This same shift is evident in the 24 June 1945 Victory Parade in Moscow, in which only male soldiers participated.

Raizman's 1945 film anticipates another emerging narrative of the war in associating Stalin with victory. The verbal commentary accompanying the raising of the flag proclaims: 'The victory banner over the Reichstag has been raised. Comrade Stalin's order has been carried out.' However, the Stalin cult in film found its fullest expression in feature films rather than documentaries. As Jaimie Baron has argued, films using 'archive footage' risk provoking a contrast between, for example, the periods, the film style or the implicit meaning of the original footage and the film quoting it. This 'creates the opportunity for multiple readings of that document' ${ }^{18}$

Soviet film in the postwar Stalin period increasingly strove to foreclose any such discontinuity between the glory of the war and its present, and any ambiguity. To that end, the 1950 film Padenie Berlina/The Fall of Berlin (Mikhail Chiaureli) uses actors playing the part of historical figures, including Stalin, in a stylistically continuous production, and forgoes the appropriation of iconic documentary footage. Its colour stock, rare for Soviet productions in this period, the enormous scale of the sets, the length (151 minutes) and the ambitious Dmitrii Shostakovich orchestral score all connote the 'epic', an inherently extensive rather than intensive form, and one habitually associated with the representation of the past and war, with glory and sacrosanct tradition. ${ }^{19}$ As Vivian Sobchack has described, the temporal magnitude and excess of the epic film construct a sense of history even within the body of the spectator who must sit for an unusually long time in the cinema. ${ }^{20}$ This creates a carnal and subjective grounding for a sense of history that is more usually framed as abstract and objective. To further underpin this evocation of epic grandeur, The Fall of Berlin reenacts elements of the familiar victory banner scene as the culminating 
point of the war, quoting Raizman's 1945 film by showing the infantry running from the behind the camera into the foreground in front of the Reichstag. In a further echo, as soon as the banner is raised over the building, the battle stops and victory celebrations begin.

In the postwar Stalin era, epic films replaced archive films such as Raizman's which could potentially challenge the Stalin cult as the source of all legitimate political and historical authority. By contrast, following Stalin's death, in the 1960s the war was reappraised and disassociated from Stalin. A shift towards personalized memory as a wave of veterans' memoirs were published was mirrored by a turn to archival footage of the war, and the genre of the compilation film became increasingly important. The raising of the Victory Banner footage was widely used in many Russian films, in documentaries such as Velikaia otechestvennaia/The Great Patriotic War (Roman Karmen, 1965), and later in Riadom so soldatom/Alongside the Soldier (Igor Gelein, 1975), both of which used a personal tone in the voiceover to stress the authenticity and testimonial qualities of the archival footage. Raizman's 1945 Victory Banner sequence serves such a representational strategy, echoing the directness and immediacy of the first-person account while still performing a politically unifying role by insisting that victory in the war belonged to the Communist Party and the Soviet system, whose banner was raised over the Reichstag.

While initially toned down in the 1960 s, the epic potential of the film was not closed off entirely; indeed the flag itself became a central point of the 1965 twentieth anniversary 9 May Victory Day parade, commemorated in a colour film of the parade, 20-letie velikogo podviga/The Twentieth Anniversary of the Great Feat (Elena Vermisheva and Irina Setkina, 1965), which features a flashback to the storming of the Reichstag sequence. A five-part feature-length film series, 
Osvobozhdenie/Liberation (Iurii Ozerov, 1968-72), devoted its final part to the raising of the banner. Liberation's use of wide-screen and colour was motivated not only by the need to create an epic visual spectacle commensurate with the significance of the events depicted, it was also intended to reassert cinema's primacy over the emerging form of television.

In 1978 a twenty-part documentary series stressing the Soviet role, The Unknown War, was broadcast, in part as a response to Thames TV's The World at War (197374),,first in the USA and only then in the USSR. While the television viewing experience is usually seen as privileging the present (so as to fragment memory and undermine a sense of historical narrative), ${ }^{21}$ and the grandeur of the film epic may be dissipated by the fact that the episodes were only fifty minutes long, the Soviet authorities took steps to ensure a more enduring and intense viewing experience by broadcasting the full series in blocks of two episodes over ten consecutive days, and in further providing extraordinarily popular theatrical screenings, ${ }^{22}$ thus retaining the 'somatic effects' of the epic film, as defined by Sobchack. The Unknown War's combining of the present tense of television with epic sweep was evident in its devotion of an entire episode (the eighteenth) to the raising of the banner.

Baron argues that the flipside to the widespread belief in the authenticity and power as evidence of what she calls 'meta-archival' documents is a desire to question and undermine those claims. ${ }^{23}$ While this may be true of iconic images generally, and more specifically in the USA, such scepticism and iconoclasm could not be publicly expressed in the Soviet Union, and did not become a significant force with regard to the Victory Banner imagery until the years following the Union's collapse in 1991, which saw a demythologizing of Soviet history, including the war. This act of demythologization was evident in memoirs that revised the canonical accounts of the 
actual raising of the banner, in popular histories, and in television films such as Igor Kholodkov's Parad veka: Znamia PobedyParade of the Century: The Victory Banner (2009), which challenged the previously accepted account as to the identity of the two soldiers who put up the first banner over the Reichstag, and stressed the staged and falsified nature of the imagery. These revisionist accounts, however, focused on the event of raising the Victory Banner and the photographs, but tended to ignore the archival film footage.

Since 2003, however, it has been precisely the filmic iconic imagery of the Victory Banner that has been widely used in the medium of the videogame, through the 2003 first person shooter game, Call of Duty, and its enormously successful 2008 fifth instalment, Call of Duty: The World at War (Activision-Blizzard). Both variants include non-interactive 'cut scenes' of the original 1945 Berlin footage, suggesting a historical authenticity that anchors the CGI action of the game, such as the assault on the Reichstag, through the point of view perspective of a Soviet combatant 'allow[ing] players to experience the movie-like intensity'. ${ }^{24}$ Indeed, reviews consistently compare the experience of playing the game with that of watching or even being in the film. ${ }^{25}$ In fact as a virtual or viewing experience it goes further: many of the scenes fill in the gaps in the iconic imagery, showing the fight inside the Reichstag itself, and the first-person point of view of the soldier hoisting the Victory Banner. The qualities of the epic narrative, endowing events with historical meaning, have gone, but the sense of being part of a small group of soldiers, the personal perspective and immediate experience remain, and are enhanced.

However, the episodes of action span a number of campaigns encompassing not only US but also British (in the first release) and Soviet characters: these qualities made it stand out from the first-person shooter game that introduced the World War II 
setting to gaming, Medal of Honor (1999), which was entirely devoted to the US experience. $^{26}$ The variety of settings and theatres of war is important, since by having action spanning various environments, the game balances the intense experience of a small group of combatants with a sense of the scale and scope of the conflict. This is particularly true of Call of Duty: The World at War: whereas the first version of Call of Duty was criticized for being too easy, with the storming of the Reichstag, including the flag-raising episode, maybe taking five or ten minutes, ${ }^{27}$ for The World at War the same event comprises two protracted episodes that are likely on a first play to consume hours of the player's time.

The need to overcome the game's difficulty, whereby the character is likely to be killed many times as the player acquires skill in completing the various missions, adds not just 'content' but a sense of the task's importance, as the hours mount up. Taking ten or twenty hours to complete the game is an investment of time, making this a gaming equivalent of the somatic experience of the epic film in its sheer temporal magnitude, coupled with a sense of the personal experience. It is surely significant that the epic trajectory culminates with the raising of the Victory Banner, mobilizing its rich associations as an image of a privileged moment of historical closure to complete the game. Thus while it recasts the footage of the Victory Banner as an interactive, palpable experience, at the same time the game 'reasserts a linear, singular, and teleological conception of history', because the narrative is predetermined, the meanings are narrowly limited. ${ }^{28}$ For all the interactivity, the narrative is always set and the player cannot change the course of historical events.

These games, designed in the USA by the world's second-largest gaming company, are played widely in Russia, especially by young people, again repurposing the meaning of the images. Many commentators have expressed their concern about 
the extent to which game-players take in the historical implications of the imagery they consume, and some suspect that the recycling and reconsumption of historical imagery distracts players from the complexities of the contemporary world and its politics. ${ }^{29}$ There can be little doubt that the games perpetuate a sense of a predetermined historical narrative, even if it may not be one consciously considered, just as they perpetuate ideas of the centrality of men and combat to war and history.

For all its conservatism, Call of Duty's mobilization of the Victory Banner imagery's momentous associations also incorporates references to the US contribution to victory, thereby diluting its exclusive focus on Soviet and Russian glory. This transnational drift of the videogame, part of a commercial strategy to appeal as widely as possible, has also elicited a response from Russian television, a bastion of national cinema, where the videogame aesthetic has influenced reworkings of the Victory Banner imagery in the miniseries Tuman2/The Fog 2 (,Ivan Shukhovetskii, STS, 2012) and Poslednii boi/The Final Fight (Ivan Shukhovetskii, STS, 2013) as well as in the penultimate episode of an eighteen-part documentary Soviet Storm: WW2 in the East (broadcast on the History Channel in 2011 in USA, 2012 in UK, and in Russia as Velikaia voina in 2010). In each case references to the imagery are framed by a fear of forgetting, an anxiety that historical memory of the raising of the victory banner has been lost, and they attempt to convey the importance of the Victory Banner symbolism and the Soviet narrative of the war to a new audience, through the idiom of the new media, by recreating the sense of immediacy, immersion and 'being there'.

Parallel to the use of new media's immediacy to promote and reinforce the symbolic potency of the banner imagery, is the parading annually since 1995 of an exact copy of the Victory Banner on Red Square for 9 May Victory Day; previously only major anniversaries such as the twentieth and fortieth had incorporated the 
banner.. This single historical instant has therefore become the centrepiece of a ritualized performance, now signifying the narrative of national Russian rather than Communist martial pride. This too is screened in rolling, multicamera, all-day Russian television coverage that is monumental in its temporal extension, sometimes with an all-week buildup. ${ }^{30}$ The moving image thus remains pivotal, spreading the iconic image's ossified vision of history across a variety of media forms: from newsreel to acted cinema, through television and the videogame to ritual reenactment.

Previous studies have often assumed that iconic photographic and film images of the same event complement each other, ${ }^{31}$ but such an account is only achieved by neglecting the 'the still moving' tension that the differences between media suggest. ${ }^{32}$ Jean Ma argues that both still and moving images, as time-based media, 'produce the sense of a present moment laden with historicity at the same time that they encourage a belief in our access to pure presence, instantaneity'. ${ }^{33}$ Yet the uses of the photographic and filmic images of the Victory Banner have not been identical. While both stand for the same vision of World War II, Khaldei's photograph appears to permit a wider historical perspective, and thus a greater sense of ambiguity, and unsurprisingly later became a site for a critique of the Soviet perspective, stressing its manipulation and debt to Rosenthal.

In this instance it is the key characteristics of the moving image that ensure the iconic imagery's enduring appeal: its editing into a single narrative of the flag-raising and the assault serves to evoke a sense of presence and immediacy that underpin its perceived authority as an authentic document. This 'archive effect' is likely to survive revelations of staging, and the footage is likely to continue to buttress epic, triumphalist narratives of the war. 
Thus, despite its migration across media and genres, the Victory Banner footage, rather than presenting semantic mutability, shows a consistent tendency to articulate the view of World War II as primarily a Soviet and Russian victory. Iconic images, it seems, are not universal, but, geographically specific.

${ }^{1}$ David Shneer, Through Soviet Jewish Eyes: Photography, War and the Holocaust (New Brunswick, NJ: Rutgers University Press, 2011).

${ }^{2}$ Victor Barbat, 'Bannières et drapeaux, sur quelques manières de les lever et de les représenter: 1'exemple du Reichstag, mai 1945', 1895, no. 74 (2014), pp. 70-95, <https://1895.revues.org/4899> accessed 4 July 2016.

${ }^{3}$ Robert Hariman and John Louis Lucaites, No Caption Needed: Iconic Photographs, Public Culture and Liberal Democracy (Chicago, IL: University of Chicago Press, 2007) p. 28.

${ }^{4}$ Ernst Volland, Das Banner des Sieges (Berlin: Berlin Story Verlag, 2008), passim.

${ }^{5}$ Hariman and J Lucaites, No Caption Needed, p. 32.

${ }^{6}$ Shneer, Through Soviet Jewish Eyes, p. 137.

${ }^{7}$ Julia Hell and Andreas Schönle, 'Introduction', in Ruins of Modernity (Durham, NC:

Duke University Press, 2010), pp. 1-16.

${ }^{8}$ Fedor Zinchenko, Geroi shturma reikhstaga (Moscow: Voennoe izdatel'stvo, 1983).

${ }^{9}$ Aleksandr Abramov and Varvara Kochetova, Znamia pobedy nad Berlinom (Nizhnii Novgorod: Ekstra N, 2007) p. 5.

10 Barbat, 'Bannières et drapeaux', pp. 87-90.

11 Shneer, Through Soviet Jewish Eyes, pp. 135-38, and Volland, Das Banner des Sieges, passim. 
${ }^{12}$ Ivan Panov, 'Nad Reichstagom znamia', in V. Zeltov and A. Lebedev (eds), Ikh oruzhie - kinokamera (Moscow: Iskusstvo, 1970), pp. 271-80.

13 Viktor Shtatland and Iulii Raizman, 'Telegram from Viktor Shtatland and Iulii Raizman to Saakov, 11 May 1945', in Central Studio of Documentary Films, Russian State Archive for Literature and Art, RGALI 2487/1/1005, 5/1.

14 Ibid.

15 Roland Barthes, Camera Lucida: Reflections on Photography. (London: Vintage Books, 2000) p.78.

${ }^{16}$ Gilles Deleuze, Cinema 1: The Movement Image (London: Continuum, 2005) p. 3.

${ }^{17}$ Anna Krylova, Soviet Women in Combat: A History of Violence on the Eastern Front (Cambridge: Cambridge University Press, 2010) pp. 3-9.

18 Jaimie Baron, The Archive Effect: Found Footage and the Audiovisual Experience of History (London: Routledge, 2014) p. 25.

${ }^{19}$ Masaki Mori, Epic Grandeur: Toward a Comparative Poetics of the Epic (Albany: State University of New York Press, 1997) p. 11

${ }^{20}$ Vivian Sobchack, 'Surge and splendor': a phenomenology of the Hollywood historical epic', Representations, no. 29 (1990), pp. 24-49.

${ }^{21}$ Steve Anderson, 'History TV and popular memory in the media age', in G. R. Edgerton and P. C. Rollins (eds), Television Histories: Shaping Collective Memory (Lexington, KT: University of Kentucky Press, 2003), pp. 19-36.

22 'O sovetskom cheloveke, o sovetskom narode', Iskusstvo kino, no. 8 (1982), pp. 94-105.

${ }^{23}$ Baron, The Archive Effect, p. 62.

${ }^{24}$ Call of Duty product description, 2003, <https://www.amazon.co.uk/Call-of-Duty$\underline{\mathrm{PC}-}$ 
$\mathrm{CD} / \mathrm{dp} / \mathrm{B} 00009 \mathrm{WBGS} ? \mathrm{ie}=\mathrm{UTF} 8 \&$ keywords $=$ call $\% 20$ of $\% 20 \mathrm{duty} \% 201 \% 2 \mathrm{C} \% 2015 \% 2$

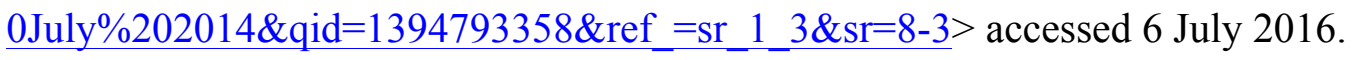

${ }^{25}$ A Customer, 'Could have been great (review of Call of Duty)', 18 November 2003, $<\underline{\text { https://www.amazon.co.uk/gp/customer- }}$

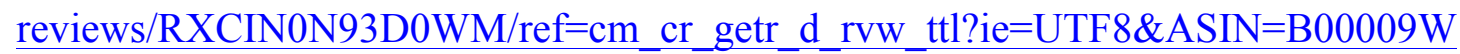

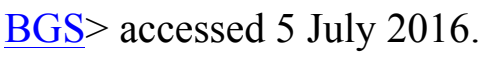

26 'Call of Duty (videogame)', Wikipedia, $<$ https://en.wikipedia.org/wiki/Call_of_Duty_(video_game)\#Soviet_campaign $\geq$ accessed 4 July 2016.

${ }^{27}$ A Customer, 'Could have been great'.

${ }^{28}$ Baron, The Archive Effect, p. 164.

${ }^{29}$ Trent Cruz, “'It's almost too intense": nostalgia and authenticity in Call of Duty 2', Loading..., vol. 1, no. 1 (2007) p. 6.

30 Stephen Hutchings and Natalia Rulyova, 'Commemorating the past/performing the present: television coverage of the second World War victory celebrations and the (de)construction of Russian nationhood', in B. Beumers, S. Hutchings and N. Rulyova (eds), The Post-Soviet Russian Media: Conflicting Signals (London: Routledge, 2009), pp. 137-55.

31 David Culbert, 'Television's visual impact on decision-making in the USA, 1968: the Tet offensive and Chicago's Democratic National Convention', Journal of Contemporary History, vol. 33, no. 3 (1998), pp. 419-49

32 Karen Beckman and Jean Ma (eds), Still Moving: Between Cinema and Photography (Durham, NC: Duke University Press, 2008) pp. 2-16, and passim.. 33 Jean Ma, 'Photography's absent times', in Beckman and Ma (eds), Still Moving, pp. $98-118$. 